\title{
Stereoselective total synthesis of antiplasmodial resorcylic acid lactone paecilomycin $\mathbf{F}$
}

\author{
Mahankali Bakkolla and Srihari Pabbaraja* \\ Division of Natural Products Chemistry, CSIR-Indian Institute of Chemical Technology, \\ Hyderabad 500 007, India \\ E-mail:srihari@iict.res.in
}

This manuscript is dedicated to Dr. J. S. Yadav on occasion of his $65^{\text {th }}$ birthday.

DOI: http://dx.doi.org/10.3998/ark.5550190.p009.183

\begin{abstract}
A facile and convergent approach for the total synthesis of 14-membered resorcylic acid lactone paecilomycin $\mathrm{F}$ is described. The synthesis emanates from the readily available inexpensive $(+)-$ diethyl L-tartrate. Mitsunobu etherification, Stille coupling and ring-closing metathesis are key steps in the synthesis.
\end{abstract}

Keywords: Macrolactone, metathesis, resorcylic acid lactone, Swern oxidation

\section{Introduction}

The impressive biological properties i.e., antifungal, ${ }^{1}$ antibiotic, ${ }^{2}$ inhibition of ATPase activity of HSP $90,{ }^{3}$ exhibited by the first resorcylic acid lactone (RAL) radicicol (Figure 1), ${ }^{4}$ a $14-$ membered benzannulated macrolide, has attracted significant attention to the related RALs ${ }^{5}$ (both synthetic and natural RALs) which have emerged over the last two decades. The resorcylic acid lactones with unique structural architecture are also found to exhibit potent biological activities ranging from antimalarial, ${ }^{6}$ antiviral, antiparasitic, ${ }^{7}$ antifungal, ${ }^{8}$ cytotoxic, ${ }^{9}$ estrogenic ${ }^{10}$ to nematocidal ${ }^{11}$ activities. Over the years, these molecules have emerged as common targets for total synthesis and have led medicinal chemists to design analog programmes leading to a number of clinical trials. ${ }^{12-15}$ Chen et al. have recently isolated six new resorcylic acid lactones, namely paecilomycin A-F ${ }^{16-18}$ (Figure 1) along with other known RALs from the mycelial solid culture of Paecilomyces fungus SC0924. Interestingly, when these compounds were subjected to screening for plasmodicidal activity, paecilomycin $\mathrm{F}$ was found to display antiplasmodial activity against Plasmodium falciparum line 3D7 with an $\mathrm{IC}_{50}$ value of $20.0 \mathrm{nM}$ and moderate activity against $P$. falciparum line Dd2. Eventhough, the structures of these compounds were determined 
by extensive NMR analysis and chemical correlations, our own investigation for the total synthesis of paecilomycin $\mathrm{E}$ and $\mathrm{F}$ lead to the structural reassignment ${ }^{18,19}$ for these two molecules and was however later reconfirmed by total synthesis from Mohapatra et $a l^{20}$ and also our group. ${ }^{21}$ In continuation of our work on the total synthesis of lactonic natural products,${ }^{22-27}$ herein we present a facile and convergent strategy for the total synthesis of paecilomycin $\mathrm{F}^{28}$<smiles>CO[C@H](C)C/C=C\C=C/C(=O)Cc1c(Cl)c(O)cc(O)c1C(=O)O</smiles>

Radicicol 1<smiles>COc1cc(OC)cc(C2OC2C[C@@H](O)[C@H](O)C(O)/C=C\CC(C)OC(=O)c2c(O)cc(OC)cc2O)c1</smiles>

Paecilomycin A 2<smiles>COc1ccc(C(=O)O[C@H](C)C/C=C/[C@H](O)[C@H]2O[C@H](O)[C@H](O)C[C@H]2O)c(O)c1</smiles>

Paecilomycin B 3<smiles>[R]C(/C=C/C[C@H](C)O)[C@@H](O)[C@@H](O)C[C@@H](O)[C@H]1Cc2cc(OC)cc(O)c2C(=O)O1</smiles>

Paecilomycin C $4: \mathrm{R}^{1}=\mathrm{H}, \mathrm{R}^{2}=\mathrm{OH}$

Paecilomycin $\mathrm{D} 5: \mathrm{R}^{1}=\mathrm{OH}, \mathrm{R}^{2}=\mathrm{H}$<smiles>[R]C([R])[C@H](O)[C@@H](O)CCC[C@@H](C)OC(=O)c1c(O)cc(OC)cc1/C=C\C</smiles>

Paecilomycin E $6: \mathrm{R}^{1}=\mathrm{OH}, \mathrm{R}^{2}=\mathrm{H}$

Paecilomycin $\mathrm{F} 7: \mathrm{R}^{1}=\mathrm{H}, \mathrm{R}^{2}=\mathrm{OH}$

Figure 1. Structures of radicicol and paecilomycins A-F.

\section{Results and Discussion}

Our retrosynthesis is based on a convergent approach and involved two key intermediates, an aliphatic chiral chain $\mathbf{8}$ comprising a double bond and a secondary alcohol, and an aromatic acid (9). These two compounds can be coupled in an esterification followed by a ring closing metathesis to provide the precursor skeleton for the target molecule. The aromatic acid $\mathbf{9}$ can be synthesized from 2,4,6-trihydroxybenzoic acid in five known steps, and the aliphatic side chain $\mathbf{8}$ can be synthesized from the alcohol $\mathbf{1 1}$ by a four step sequence, i.e. oxidation, allylation, MOM protection of the resulting allyl alcohol, and deprotection of the TBDPS moiety (Scheme 1). The alcohol 11 can be synthesized from alkyne 12 in a one-pot reaction through hydrogenation, which in turn can be synthesized by a coupling reaction of terminal alkyne $\mathbf{1 3}$ with triflate $\mathbf{1 4}$. The triflate is easily accessible from the commercially available (+)-diethyl L-tartrate $(\mathrm{L}(+)-\mathrm{DET})$. 


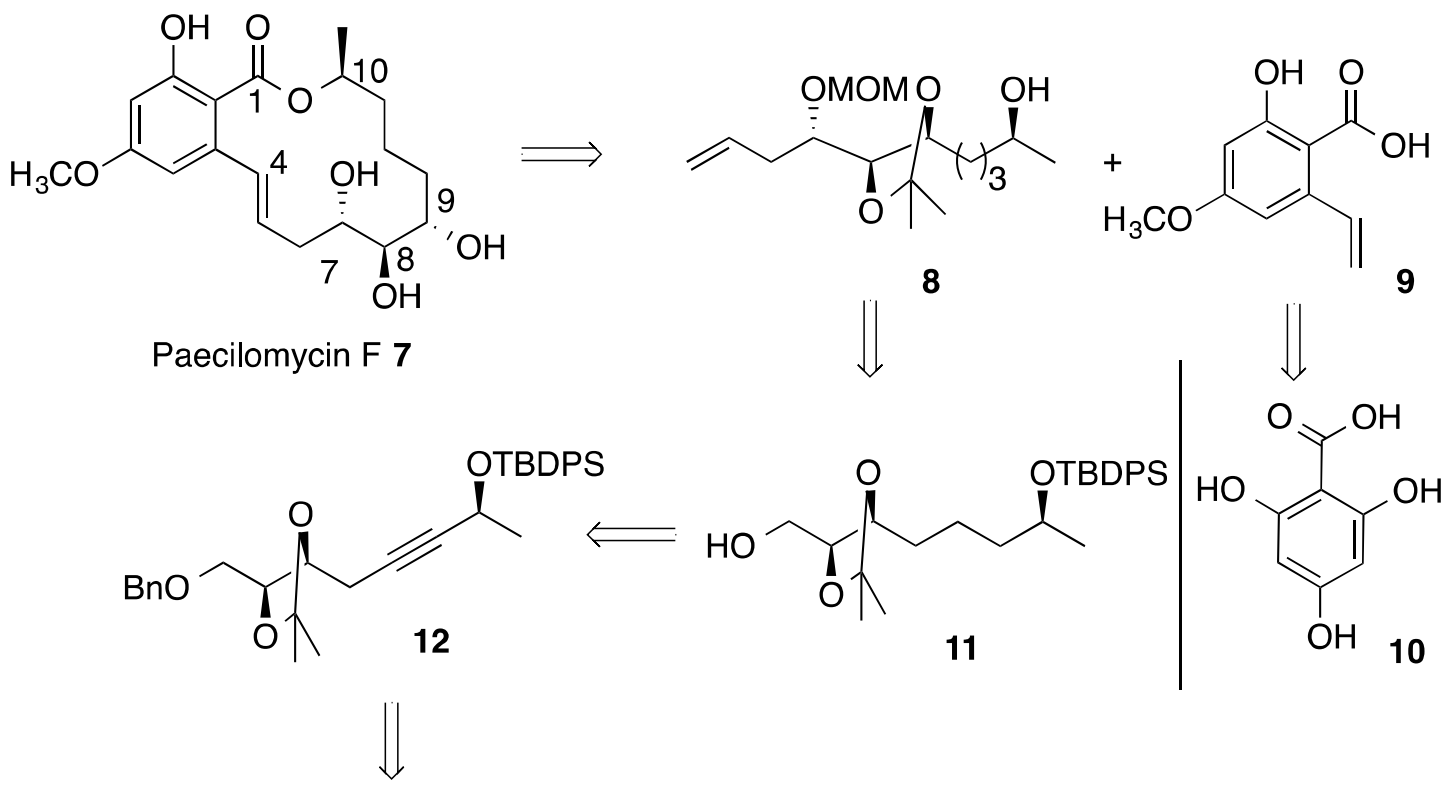

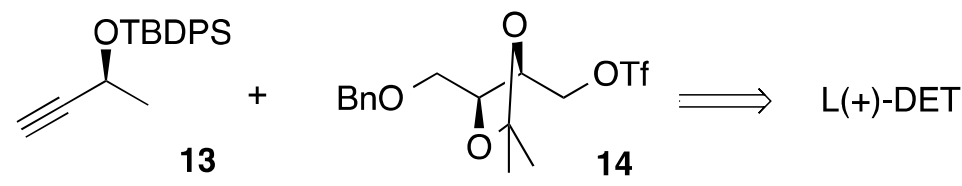

Scheme 1. Retrosynthesis of paecilomycin F.

The synthesis began with isopropylidene protection $^{29}$ of the readily available (+)-diethyl Ltartrate to get the corresponding acetonide product $\mathbf{1 5}$ followed by the diester reduction with lithium aluminium hydride to deliver 1,4-diol 16. The diol $\mathbf{1 6}$ was sequentially protected as the corresponding benzyl ether $\mathbf{1 7}$ by treatment with benzyl bromide and $\mathrm{NaH}$ and activated as the triflate 14 by triflic anhydride in presence of 2,6-lutidine to set up the stage for coupling with the terminal acetylene 13. The alkyne $\mathbf{1 3}$ (obtained from the commercially available $(S)$-but-3-yne-2ol after protection with TBDPSCl) was metalated with $\mathrm{n}-\mathrm{BuLi}$ in presence of hexamethylphosphoramide (HMPA) and treated with triflate 14 to furnish the di-substituted alkyne 12. ${ }^{30}$ One pot benzyl deprotection and alkyne reduction was achieved smoothly with $\mathrm{Pd} / \mathrm{C}$ under hydrogen atmosphere to provide the primary alcohol 11 in good yield (Scheme 2). The alcohol 11 was oxidized under Swern conditions ${ }^{31}$ to yield the aldehyde and then subjected to allylation with allyl bromide in presence of $\mathrm{Zinc}^{32}$ and $\mathrm{NH}_{4} \mathrm{Cl}$ and further treated with $\mathrm{MOM}-\mathrm{Cl}$ to furnish the corresponding MOM ethers. The product obtained after allylation was a mixture of diastereomers, which were inseparable and were directly treated with $\mathrm{MOM}-\mathrm{Cl}$ to get the corresponding MOM ethers (9:1) which were easily separable by column chromatography. Based on the earlier experience for the allylation reaction, ${ }^{19,21}$ we proceeded further with the major diastereomer 18. Thus, treatment of the major diastereomer 18 with TBAF resulted in the formation of $\mathbf{8}$, the key side chain fragment with the required stereochemistry. 
The other key fragment aromatic acid 9 was synthesized starting from 2,4,6trihydroxybenzoic acid 10 (THBA) following known protocols as shown in Scheme 3. Thus, THBA 10 was treated with trifluoroacetic acid (TFA) and trifluoroacetic anhydride (TFAA) following Danishefsky's protocol ${ }^{33}$ to get the acetonide protected product 19 . The regioselective methylation of $\mathbf{1 9}$ at para- position to carboxylic functionality was easily achieved with $\mathrm{MeOH}$ under Mitsunobu conditions ${ }^{34}$ to yield $\mathbf{2 0}$ in $85 \%$ yield. The free hydroxyl group in $\mathbf{2 0}$ ortho- to carboxylic acid functionality was activated by converting it to the corresponding triflate $\mathbf{2 1}$ with triflic anhydride and later subjected to Stille coupling ${ }^{35}$ with n-tributyl(vinyl tin) to furnish the vinylated aromatic ester 22 (Scheme 3). Ester hydrolysis of 22 with $\mathrm{LiOH}$ at room temperature provided the aromatic acid 9 in $86 \%$ yield, which can be used for coupling reaction towards the target synthesis.<smiles>[Z10]OC(=O)[C@H](O)[C@@H](O)C(=O)OCC</smiles>

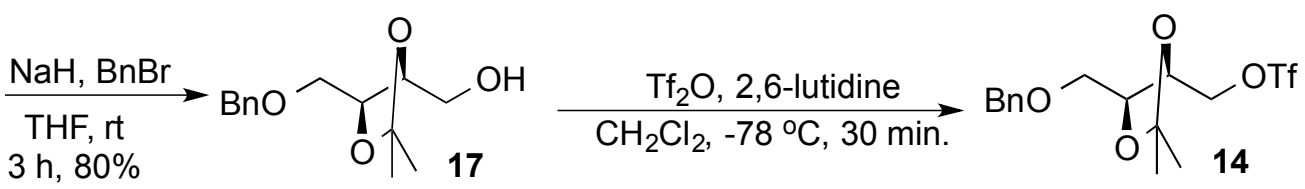

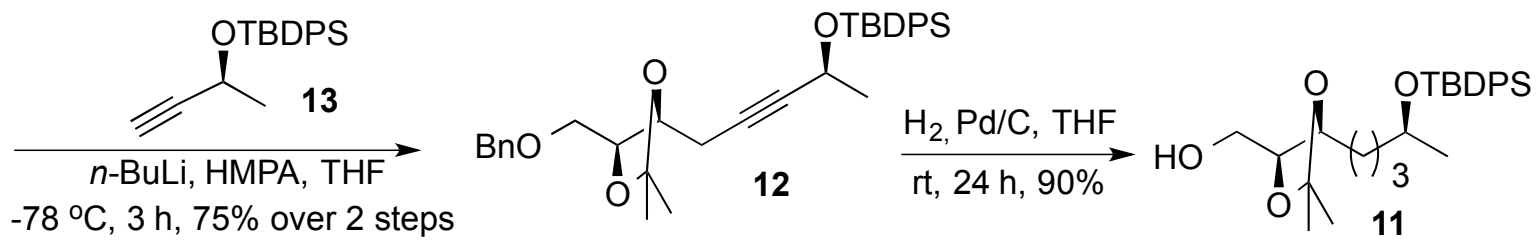

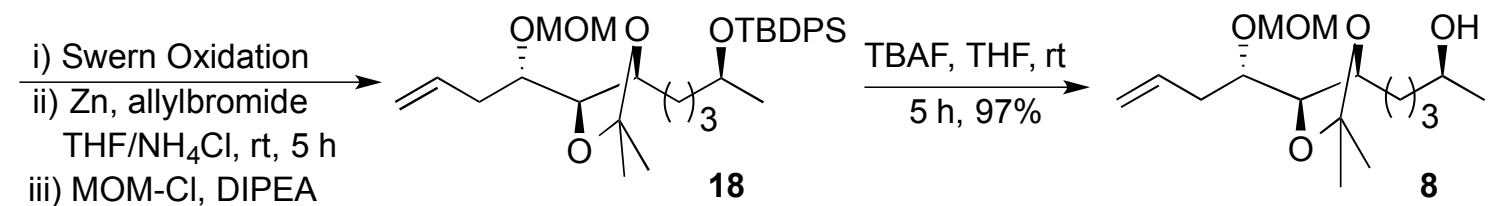

iii) MOM-Cl, DIPEA

18

8

$\mathrm{CH}_{2} \mathrm{Cl}_{2}$, rt, $6 \mathrm{~h}$

$63 \%$ overall for 3 steps

Scheme 2. Synthesis of aliphatic chiral key intermediate 8.

With the two key intermediates $\mathbf{8}$ and $\mathbf{9}$ in hand, the stage was set to proceed further for coupling to get the macrocyclic core skeleton. This was performed under Steglich esterification conditions $^{36}$ to furnish the ester 23 in $67 \%$ yield. Although, our initial attempts at ring-closing 
metathesis of $\mathbf{2 3}$ with Grubbs first generation catalyst did not succeed and ended up with the recovery of starting material, the reaction was successful with Grubbs second generation catalyst ${ }^{37}$ in $\mathrm{CH}_{2} \mathrm{Cl}_{2}$ at room temperature to provide the desired core structure $\mathbf{2 4}$ exclusively in $85 \%$ yield (Scheme 4 ). The geometry of the product was characterized based on the coupling constant value of $14.9 \mathrm{~Hz}$ for the olefinic protons. The compound 24 when exposed to $2 \mathrm{~N} \mathrm{HCl}$ for $15 \mathrm{~h}$ underwent complete deprotection of MOM and acetonide functionalities furnishing the target molecule paecilomycin F. The spectroscopic data of the synthesized product was in full agreement with the reported data ${ }^{16,18}$ of the natural product (See table 1).<smiles>COc1cc(O)c2c(c1)OC(C)(C)OC2=O</smiles><smiles>C=Cc1cc(OC)cc(O)c1C(=O)O</smiles>

Scheme 3. Synthesis of aromatic acid 9.

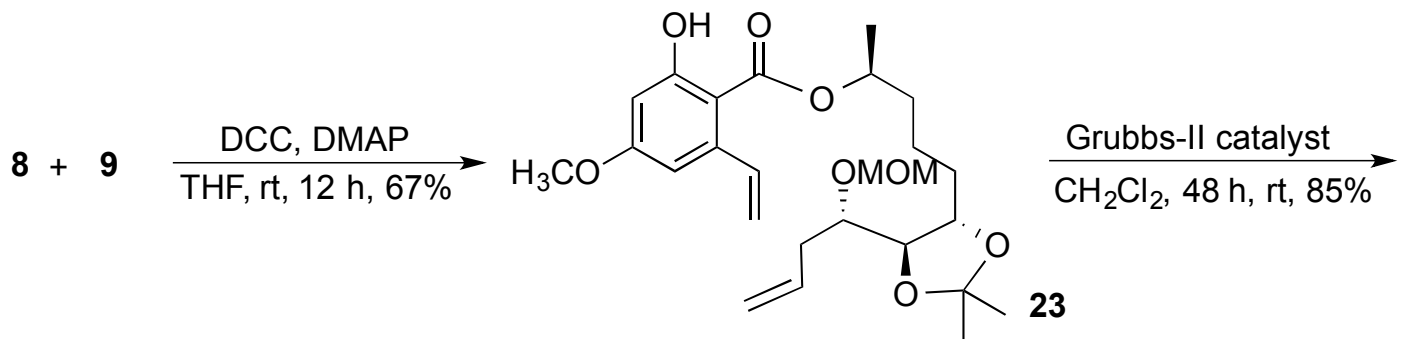

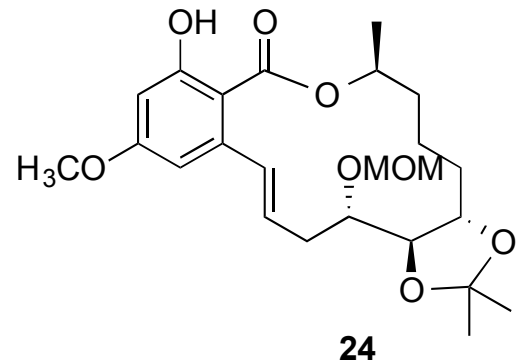

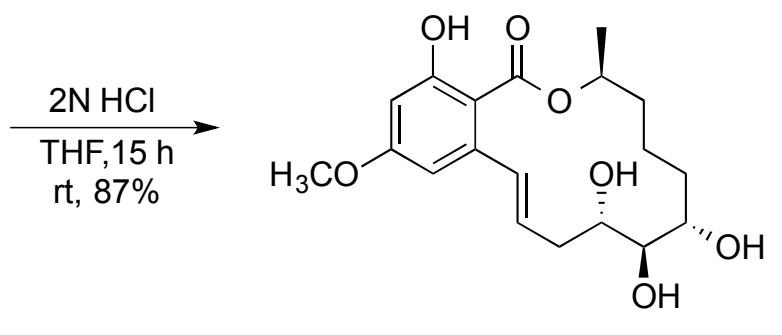

Paecilomycin F 7

Scheme 4. Conclusion of synthesis of paecilomycin F 7. 
Table 1. Comparative ${ }^{1} \mathrm{H}$ and ${ }^{13} \mathrm{C}$ NMR data of natural and synthetic paecilomycin $\mathrm{F}$

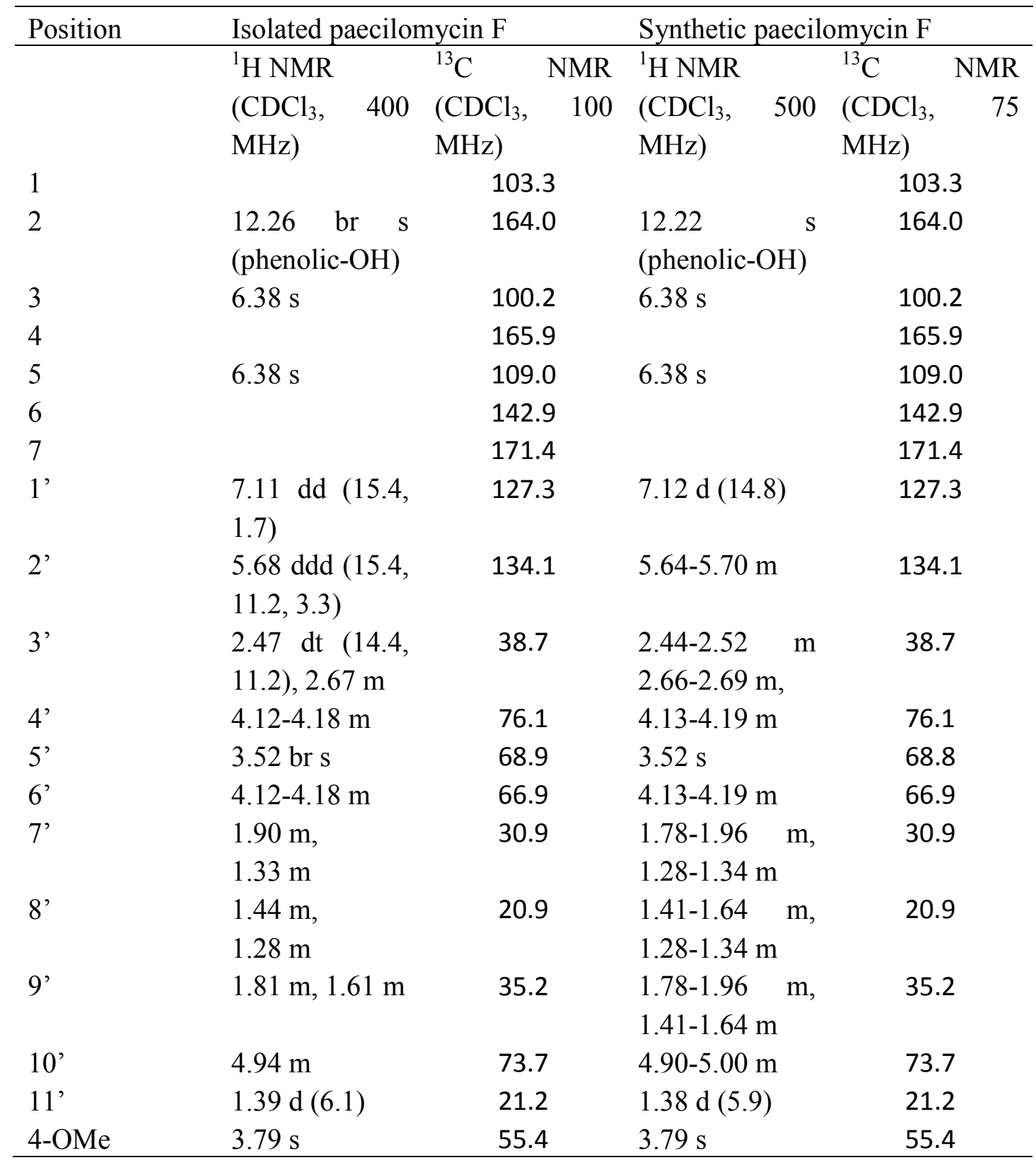

\section{Conclusions}

We have achieved a total synthesis of paecilomycin F from the readily available (+)-diethyl Ltartrate. Ring closing metathesis and standard DCC, DMAP coupling (Steglich esterification) have been once again pivotal for constructing the macrocycle core. The synthesis involved 12 steps with an overall yield of $14 \%$. Synthesis of other paecilomycins are currently being investigated in our laboratory. 


\section{Experimental Section}

General. Column chromatography was performed using silica gel 60-120 mesh. All the solvents were dried and distilled prior to use. IR spectra were recorded on a Perkin-Elmer Infrared spectrophotometer as neat or in $\mathrm{CHCl}_{3}$ as a thin film or as $\mathrm{KBr}$ wrafers. ${ }^{1} \mathrm{H}$ and ${ }^{13} \mathrm{C}$ NMR were recorded on a Bruker Avance $300 \mathrm{MHz}$ instrument using TMS as internal standard. Mass spectra were recorded on Micromass VG 7070H mass spectrometer for EI, VG Autospec mass spectrometer for FABMS and micromass Quatro LC triple quadrupole mass spectrometer for ESI analysis. The optical rotations were recorded on a MCP 200 modular circular polarimeter. $\mathrm{L}(+)-$ DET, $P$ TSA, LAH, BnBr, Tf $2 \mathrm{O},(S)$-but-3-yn-2-ol, HMPA, and vinylstannane were purchased from Sigma-Aldrich. 2,6-Lutidine, allyl bromide, TFA, TFAA, TPP, DIAD were purchased from Spectrochem, and all these reagents were directly utilized for the reactions.

Diethyl (4R,5R)-2,2-dimethyl-1,3-dioxolane-4,5-dicarboxylate (15). A solution of (+)-diethyl L-tartrate $(20.0 \mathrm{~g}, 97.08 \mathrm{mmol})$ and $p$-toluenesulfonic acid $(184 \mathrm{mg}, 0.97 \mathrm{mmol})$ in benzene (50 $\mathrm{mL})$ and 2,2-dimethoxypropane $(17.8 \mathrm{~mL}, 145.63 \mathrm{mmol})$ was heated under reflux for $15 \mathrm{~h}$. The mixture was allowed to cool to ambient temperature. The reaction mixture was washed with aq. saturated sodium bicarbonate solution $(50 \mathrm{~mL})$, dried over anhydrous $\mathrm{Na}_{2} \mathrm{SO}_{4}$. The solvent was evaporated and the residue was purified by column chromatography (hexane/EtOAc 8:2) to give product 15 as a colorless liquid $(21.5 \mathrm{~g}, 90 \%) . R_{f} 0.7$ (hexane/EtOAc 7:3). $[\alpha]^{20}{ }_{\mathrm{D}}+42.9(c 1.0$, $\mathrm{MeOH})$; Lit. $^{38}[\alpha]^{20}{ }_{\mathrm{D}}+41.2$ (c 1.0, MeOH). IR (neat): 2990, 2942, 1758, 1450, 1375, 1255, 1211, 1111, 1026, $856 \mathrm{~cm}^{-1} .{ }^{1} \mathrm{H}$ NMR $\left(300 \mathrm{MHz}, \mathrm{CDCl}_{3}\right): \delta$ 4.66-4.62 (m, 2H), 4.20 (q, $J 7.5$ $\mathrm{Hz}, 4 \mathrm{H}), 1.42(\mathrm{~s}, 6 \mathrm{H}), 1.27(\mathrm{t}, J \quad 7.5 \mathrm{~Hz}, 6 \mathrm{H}) .{ }^{13} \mathrm{C} \mathrm{NMR}\left(75 \mathrm{MHz}, \mathrm{CDCl}_{3}\right): \delta 169.6,113.0,76.7$, 61.4, 26.4, 14.0. MS (ESI): $m / z 269$ [M+Na]. HRMS (ESI): calcd for $\mathrm{C}_{11} \mathrm{H}_{18} \mathrm{NaO}_{6} 269.1001$, found 269.0992 .

(4S,5S)-(2,2-Dimethyl-1,3-dioxolane-4,5-diyl)dimethanol (16). A solution of compound 15 $(10.0 \mathrm{~g}, 40.65 \mathrm{mmol})$ in THF $(50 \mathrm{~mL})$ was slowly added to a suspension of $\mathrm{LiAlH}_{4}(3.08 \mathrm{~g}$, $81.30 \mathrm{mmol})$ in THF $(50 \mathrm{~mL})$ at $0{ }^{\circ} \mathrm{C}$ over a period of $30 \mathrm{~min}$. The resulting mixture was heated at $40{ }^{\circ} \mathrm{C}$ for $5 \mathrm{~h}$ to complete the reduction. The reaction was carefully quenched with saturated aqueous $\mathrm{Na}_{2} \mathrm{SO}_{4}(10 \mathrm{~mL})$ at $0{ }^{\circ} \mathrm{C}$ and the resulting suspension was stirred for $3 \mathrm{~h}$ before it was filtered through a pad of silica gel. The filtrate was dried over $\mathrm{Na}_{2} \mathrm{SO}_{4}$, the solvent was evaporated and the residue purified by column chromatography (hexane/EtOAc 1:1) to give diol 16 as a colorless liquid (6.25 g, 95\%). $R_{f} 0.3$ (hexane/EtOAc 6:4); $[\alpha]^{20}{ }_{\mathrm{D}}+11.2(c 1.0, \mathrm{MeOH})$; Lit. $^{37}[\alpha]^{20}{ }_{\mathrm{D}}+10.8(c$ 0.5, MeOH). IR (neat): 3401, 2988, 2935, 2881, 1376, 1251, 1218, 1165 , 1108, 1053, $844 \mathrm{~cm}^{-1} .{ }^{1} \mathrm{H}$ NMR $\left(300 \mathrm{MHz}, \mathrm{CDCl}_{3}\right): \delta$ 3.97-3.89 (m, $\left.2 \mathrm{H}\right), 3.76-3.65(\mathrm{~m}, 4 \mathrm{H})$, 1.39 (s, 6H). ${ }^{13} \mathrm{C}$ NMR (75 MHz, $\mathrm{CDCl}_{3}$ ): $\delta 109.2,78.3,62.0,26.8$. MS (ESI): $m / z 185$ [M+Na]. HRMS (ESI): calcd for $\mathrm{C}_{7} \mathrm{H}_{14} \mathrm{NaO}_{4}$ 185.0789, found 185.0786.

(4S,5S)-[5-(Benzyloxymethyl)-2,2-dimethyl-1,3-dioxolan-4-yl]methanol (17). A solution of diol $16(5.0 \mathrm{~g}, 30.86 \mathrm{mmol})$ in THF $(30 \mathrm{~mL})$ was slowly added over a period of $30 \mathrm{~min}$ to a suspension of $\mathrm{NaH}(1.35 \mathrm{~g}, 30.86 \mathrm{mmol})$ in $\mathrm{THF}(30 \mathrm{~mL})$ at $0{ }^{\circ} \mathrm{C}$ and the resulting mixture was 
stirred at ambient temperature for $1 \mathrm{~h}$ until the evolution of gas had ceased and then cooled to 0 ${ }^{\circ} \mathrm{C}$. To this mixture was added a solution of benzyl bromide $(3.6 \mathrm{~mL}, 30.86 \mathrm{mmol})$ in THF (30 $\mathrm{mL}$ ) dropwise over $30 \mathrm{~min}$ and the resulting mixture was stirred for $3 \mathrm{~h}$. The reaction mixture was poured into crushed ice $(300 \mathrm{~mL})$ and extracted with EtOAc $(120 \mathrm{~mL})$. The organic layer was washed with brine $(50 \mathrm{~mL})$, dried over anhydrous $\mathrm{Na}_{2} \mathrm{SO}_{4}$, filtered and concentrated under reduced pressure. The resulting residue was purified by column chromatography (hexane/EtOAc $8: 2)$ on silica gel to afford compound $\mathbf{1 7}$ as a pale yellow coloured liquid ( $6.27 \mathrm{~g}, 80 \%$ yield). $R_{f}$ 0.6 (hexane/EtOAc 6:4); $[\alpha]^{20}{ }_{\mathrm{D}}+8.3\left(c\right.$ 1.0, $\left.\mathrm{CHCl}_{3}\right), \mathrm{Lit}^{38}{ }^{38}[\alpha]_{\mathrm{D}}^{23}+8.2\left(c\right.$ 1.0, $\left.\mathrm{CHCl}_{3}\right)$. IR (neat): $3466,2988,2932,2872,1453,1375,1250,1216,1167,1085,847,741,699 \mathrm{~cm}^{-1}$. ${ }^{1} \mathrm{H}$ NMR (300 $\left.\mathrm{MHz}, \mathrm{CDCl}_{3}\right): \delta 7.34-7.24(\mathrm{~m}, 5 \mathrm{H}), 4.56(\mathrm{~s}, 2 \mathrm{H}), 4.02-3.96(\mathrm{~m}, 1 \mathrm{H}), 3.92-3.86(\mathrm{~m}, 1 \mathrm{H}), 3.74-$ $3.63(\mathrm{~m}, 3 \mathrm{H}), 3.54-3.48(\mathrm{~m}, 1 \mathrm{H}), 2.18$ (br s, 1H), 1.39 (s, $3 \mathrm{H}), 1.38(\mathrm{~s}, 3 \mathrm{H})$.

${ }^{13} \mathrm{C}$ NMR (75 MHz, $\mathrm{CDCl}_{3}$ ): $\delta$ 137.4, 128.3 (2C), 127.6, 127.5 (2C), 109.2, 79.4, 76.3, 73.4, 70.2, 62.2, 26.8, 26.7. MS (ESI): $m / z 275$ [M+Na]. HRMS (ESI): calcd for $\mathrm{C}_{14} \mathrm{H}_{20} \mathrm{NaO}_{4}$ 275.1259 , found 275.1249 .

(S)-(But-3-yn-2-yloxy)(t-butyl)diphenylsilane (13). TBDPSCl (4.4 mL, $17.14 \mathrm{mmol})$ was slowly added to a solution of $(S)$-but-3-yn-2-ol (1.0 g, $14.28 \mathrm{mmol})$ and imidazole $(3.75 \mathrm{~mL}$, $35.7 \mathrm{mmol})$ in $\mathrm{CH}_{2} \mathrm{Cl}_{2}(20 \mathrm{~mL})$ at $0{ }^{\circ} \mathrm{C}$ and the resulting mixture was stirred for $15 \mathrm{~h}$ at room temperature. After $15 \mathrm{~h}, \mathrm{CH}_{2} \mathrm{Cl}_{2}(10 \mathrm{~mL})$ and $\mathrm{H}_{2} \mathrm{O}(20 \mathrm{~mL})$ were added. The layers were separated and the aqueous phase extracted with $\mathrm{CH}_{2} \mathrm{Cl}_{2}(3 \times 20 \mathrm{~mL})$. The combined organic phase was washed with brine $(20 \mathrm{~mL})$, dried over $\mathrm{Na}_{2} \mathrm{SO}_{4}$, concentrated under reduced pressure, and purified by silica gel column chromatography (hexane/EtOAc 98:2) to afford 13 (3.87 $\mathrm{g}$, 94\%) as a colorless oil. $R_{f} 0.8$ (hexane/EtOAc 95:5); $[\alpha]^{20}{ }_{\mathrm{D}}-61.20$ (c 2.0, $\mathrm{CHCl}_{3}$ ). IR (neat): $3302,2958,2934,2859,1428,1107,1058,975,703 \mathrm{~cm}^{-1} .{ }^{1} \mathrm{H}$ NMR $\left(300 \mathrm{MHz}, \mathrm{CDCl}_{3}\right): \delta 7.77-$ $7.73(\mathrm{~m}, 2 \mathrm{H}), 7.70-7.66(\mathrm{~m}, 2 \mathrm{H}), 7.46-7.34(\mathrm{~m}, 6 \mathrm{H}), 4.45$ (qt, $J$ 6.5, $2.1 \mathrm{~Hz}, 1 \mathrm{H}), 2.34$ (d, $J 2.1$ $\mathrm{Hz}, 1 \mathrm{H}), 1.39$ (d, J 6.5 Hz, 3H), 1.08 (s, 9H). ${ }^{13} \mathrm{C} \mathrm{NMR} \mathrm{(75} \mathrm{MHz,} \mathrm{CDCl}_{3}$ ): $\delta 135.9(2 \mathrm{C}), 135.7$ (2C), 133.6, 133.4, 129.7, 129.6, 127.6 (2C), 127.5 (2C), 127.4, 86.0, 71.5, 59.7, 26.8 (3C), 25.1, 19.1. MS (APCI): $\mathrm{m} / z 309[\mathrm{M}+\mathrm{H}]^{+}$. Anal. calcd for $\mathrm{C}_{20} \mathrm{H}_{24} \mathrm{OSi}$ : C 77.87, H 7.84; found: $\mathrm{C} 77.55$, H $7.68 \%$.

[I(S)-5-[(4S,5S)-5-((Benzyloxy)methyl)-2,2-dimethyl-1,3-dioxolan-4-yl]pent-3-yn-2-yl]oxy](tbutyl)diphenylsilane (12). To a solution of compound 17 (700 mg, $2.78 \mathrm{mmol})$ in $\mathrm{CH}_{2} \mathrm{Cl}_{2}(20$ $\mathrm{mL}$ ) was added a solution of trifluoromethanesulfonic anhydride $(0.5 \mathrm{~mL}, 3.05 \mathrm{mmol})$ at $-78{ }^{\circ} \mathrm{C}$ over $5 \mathrm{~min}$, and the resulting solution was stirred for $30 \mathrm{~min}$. To the reaction mixture was added saturated $\mathrm{NH}_{4} \mathrm{Cl}(5 \mathrm{~mL})$ with $\mathrm{CH}_{2} \mathrm{Cl}_{2}(40 \mathrm{~mL})$. The organic layer was washed with brine (10 $\mathrm{mL}$ ), dried over $\mathrm{Na}_{2} \mathrm{SO}_{4}$, and concentrated under reduced pressure to give the crude product $(0.9$ g) as pale yellow oil. The product was passed through short pad of silica gel column chromatography (hexane/EtOAc 9:1) to afford crude $14(1.01 \mathrm{~g}, 95 \%)$ as a colorless oil. $R_{f} 0.8$ (hexane/EtOAc 7:3). A solution of n-BuLi (1.46 mL of a 1.6 M solution in hexane, $2.34 \mathrm{mmol}$ ) was added dropwise to a solution of compound $13(0.818 \mathrm{~g}, 2.6 \mathrm{mmol})$ in THF $(15 \mathrm{~mL})$ over 5 $\min$ at $0{ }^{\circ} \mathrm{C}$. Once addition was complete, the reaction mixture was warmed to $\mathrm{rt}$ for $1 \mathrm{~h}$, then recooled to $-78{ }^{\circ} \mathrm{C}$. HMPA $(1.6 \mathrm{~mL}, 9.36 \mathrm{mmol})$ was added via syringe, and the resultant 
solution was stirred for $10 \mathrm{~min}$. A solution of compound $14(0.6 \mathrm{~g}, 1.56 \mathrm{mmol})$ in THF $(10 \mathrm{~mL})$ was added dropwise over $5 \mathrm{~min}$. The mixture was stirred at $\mathrm{rt}$ for $6 \mathrm{~h}$, then quenched with saturated aqueous $\mathrm{NH}_{4} \mathrm{Cl}(10 \mathrm{~mL})$. The layers were separated, and aqueous phase was extracted with EtOAc $(3 \times 20 \mathrm{~mL})$. The combined organic phase was washed with brine $(20 \mathrm{~mL})$, dried over anhydrous $\mathrm{Na}_{2} \mathrm{SO}_{4}$, filtered and concentrated under reduced pressure. The crude product was purified by silica gel column chromatography (hexane/EtOAc 9:1) to afford $12(0.760 \mathrm{~g}$, $75 \%$ ) as a colorless oil. $R_{f} 0.4$ (hexane/EtOAc 9:1); $[\alpha]^{20}{ }_{\mathrm{D}}-59.0$ (c 2.0, $\mathrm{CHCl}_{3}$ ). IR (neat): 3540, 3069, 2932, 2859, 1457, 1429, 1373, 1246, 1215, 1108, 822, $738 \mathrm{~cm}^{-1} .{ }^{1} \mathrm{H}$ NMR (500 MHz, $\left.\mathrm{CDCl}_{3}\right): \delta$ 7.74-7.66 (m, 4H), 7.43-7.26 (m, 11H), 4.59-4.52 (m, 2H), 4.41-4.40 (m, 1H), 3.97$3.94(\mathrm{~m}, 1 \mathrm{H}), 3.82-3.78(\mathrm{~m}, 1 \mathrm{H}), 3.69-3.51(\mathrm{~m}, 2 \mathrm{H}), 2.49-2.40(\mathrm{~m}, 2 \mathrm{H}), 1.40(\mathrm{~s}, 3 \mathrm{H}), 1.39(\mathrm{~s}$, $3 \mathrm{H}), 1.33(\mathrm{~d}, J 6.3 \mathrm{~Hz}, 3 \mathrm{H}), 1.06(\mathrm{~s}, 9 \mathrm{H}) .{ }^{13} \mathrm{C} \mathrm{NMR}\left(75 \mathrm{MHz}, \mathrm{CDCl}_{3}\right) \delta 138.0,135.9(2 \mathrm{C}), 135.7$ (2C), 134.8, 133.8, 133.7, 129.6, 129.5, 128.3 (2C), 127.6 (2C), 127.5 (2C), 127.4 (2C), 109.2, 84.9, 79.6, 79.1, 75.6, 73.5, 70.6, 59.9, 27.1, 27.0, 26.8 (3C), 25.3, 23.0, 19.1. MS (ESI) for $\mathrm{C}_{34} \mathrm{H}_{42} \mathrm{O}_{4} \mathrm{SiNa}: m / z 565[\mathrm{M}+\mathrm{Na}]$.

(4S,5S)-5-[[2-[(tert-Butyldiphenylsilyl)oxy]propyl]-2,2-dimethyl-1,3-dioxolan-4-yl]methanol (11). The compound $12(0.55 \mathrm{~g}, 1.2 \mathrm{mmol})$ was dissolved in THF $(20 \mathrm{~mL})$ and commercial $\mathrm{Pd} / \mathrm{C}$ $(55 \mathrm{mg}, 10 \% \mathrm{w} / \mathrm{w})$ was added. The resulting suspension was stirred under an atmosphere of $\mathrm{H}_{2}$ for $15 \mathrm{~h}$ until complete conversion of the substrate occurred. The suspension was filtered through celite which was rinsed with EtOAc $(150 \mathrm{~mL})$. The combined filtrates were washed with brine $(30 \mathrm{~mL})$, dried over anhydrous $\mathrm{Na}_{2} \mathrm{SO}_{4}$, filtered and concentrated under reduced pressure. The crude product was purified by silica gel column chromatography (hexane/EtOAc 8:2) to afford 11 as a colorless liquid (414 mg, 90\%). $R_{f} 0.3$ (hexane/EtOAc 8:2); $[\alpha]^{20}{ }_{\mathrm{D}}-17.50\left(c\right.$ 1.2, $\left.\mathrm{CHCl}_{3}\right)$. IR (neat): $3463,2932,2859,1428,1374,1242,1218,1107,1049,703 \mathrm{~cm}^{-1} .{ }^{1} \mathrm{H}$ NMR $(300 \mathrm{MHz}$, $\left.\mathrm{CDCl}_{3}\right): \delta$ 7.69-7.66 (m, 4H), 7.44-7.33 (m, 6H), 3.88-3.63 (m, 3H), 3.69-3.63 (m, $\left.1 \mathrm{H}\right), 3.58-$ $3.50(\mathrm{~m}, 1 \mathrm{H}), 1.53-1.32(\mathrm{~m}, 12 \mathrm{H}), 1.07(\mathrm{~s}, 3 \mathrm{H}), 1.05(\mathrm{~s}, 9 \mathrm{H}) .{ }^{13} \mathrm{C}$ NMR $\left(75 \mathrm{MHz}, \mathrm{CDCl}_{3}\right): \delta$ 135.8 (4C), 134.8, 134.5, 129.4, 129.3, 127.4 (2C), 127.3 (2C), 108.5, 81.4, 76.8, 69.3, 62.0, 39.3, 33.0, 27.3 (2C), 27.0 (3C), 23.1, 21.5, 19.2. MS (ESI): $m / z 479$ [M+Na]. HRMS (ESI): calcd for $\mathrm{C}_{27} \mathrm{H}_{40} \mathrm{O}_{4} \mathrm{SiNa} 479.2593$, found 479.2612

tert-Butyl-[[(S)-1-[(4S,5S)-5-[(S)-1-(methoxymethyloxy)but-3-en-1-yl]-2,2-dimethyl-1,3-dioxolan-4-yl]propan-2-yl]oxy]diphenylsilane (18). To a solution of oxalyl chloride $(0.11 \mathrm{~mL}$, $1.14 \mathrm{mmol})$ in $\mathrm{CH}_{2} \mathrm{Cl}_{2}(5 \mathrm{~mL})$ was added a solution of DMSO $(0.19 \mathrm{~mL}, 2.63 \mathrm{mmol})$ in $\mathrm{CH}_{2} \mathrm{Cl}_{2}$ $(2 \mathrm{~mL})$ at $-78{ }^{\circ} \mathrm{C}$, and the resulting solution was stirred for $10 \mathrm{~min}$ at the same temperature. A solution of the alcohol $11(0.3 \mathrm{~g}, 0.657 \mathrm{mmol})$ in $\mathrm{CH}_{2} \mathrm{Cl}_{2}(3 \mathrm{~mL})$ was added dropwise over 5 min. After the solution had stirred for an additional $30 \mathrm{~min}, \mathrm{Et}_{3} \mathrm{~N}(0.548 \mathrm{~mL}, 3.942 \mathrm{mmol})$ was added and the reaction mixture was allowed to warm to room temperature. The reaction mixture was poured into $\mathrm{H}_{2} \mathrm{O}$, extracted with $\mathrm{CH}_{2} \mathrm{Cl}_{2}(2 \times 10 \mathrm{~mL})$. The organic layers were washed with brine $(10 \mathrm{~mL})$, dried over $\mathrm{Na}_{2} \mathrm{SO}_{4}$, and concentrated under reduced pressure to give the crude aldehyde $(2.3 \mathrm{~g})$ as pale yellow oil. To a pre-cooled $\left(10^{\circ} \mathrm{C}\right)$ and well-stirred mixture of crude aldehyde $(0.3 \mathrm{~g}, 0.657 \mathrm{mmol})$ in THF $(5 \mathrm{~mL})$, zinc dust $(0.172 \mathrm{~g}, 2.64 \mathrm{mmol})$ and allyl bromide $(0.112$ $\mathrm{mL}, 1.32 \mathrm{mmol})$ in THF $(5 \mathrm{~mL})$ was added a saturated aqueous solution of $\mathrm{NH}_{4} \mathrm{Cl}(0.1 \mathrm{~mL})$ in 
portions over a period of $10 \mathrm{~min}$. The reaction started vigorously soon after the addition of the first portion of the salt solution. The mixture was stirred for $5 \mathrm{~h}$ till the complete disappearance of the aldehyde (TLC). The reaction was quenched with MOM-Cl $(0.084 \mathrm{~mL}, 1.058 \mathrm{mmol})$ at 0 ${ }^{\circ} \mathrm{C}$ and the resulting mixture was stirred for $6 \mathrm{~h}$ at room temperature. The mixture was filtered and washed with EtOAc $(50 \mathrm{~mL})$. Solvent removal under reduced pressure and column chromatography of the residue (hexane/EtOAc 98:2) afforded 18 as a colorless liquid $(0.205 \mathrm{~g}$, 63\%). $R_{f} 0.8$ (hexane/EtOAc 9:1); $[\alpha]^{20}{ }_{\mathrm{D}}-18.63$ (c 0.8, $\mathrm{CHCl}_{3}$ ). IR (neat): 3453, 2932, 1635, 1399, 1217, 1107, 1037, $760 \mathrm{~cm}^{-1} .{ }^{1} \mathrm{H}$ NMR $\left(300 \mathrm{MHz}, \mathrm{CDCl}_{3}\right): \delta$ 7.69-7.67 (m, 4H), 7.41-7.33 $(\mathrm{m}, 6 \mathrm{H}), 5.94-5.80(\mathrm{~m}, 1 \mathrm{H}), 5.16-5.08(\mathrm{~m}, 2 \mathrm{H}), 4.68(\mathrm{~s}, 2 \mathrm{H}), 3.94-3.82(\mathrm{~m}, 2 \mathrm{H}), 3.74-3.65(\mathrm{~m}$, 2H), 3.37 (s, 3H), 2.39-2.36 (m. 2H), 1.60-1.43 (m, 6H), 1.36 (s, 6H), 1.07 (s, 3H), 1.04 (s, 9H). ${ }^{13} \mathrm{C}$ NMR $\left(75 \mathrm{MHz}, \mathrm{CDCl}_{3}\right): \delta 135.8(4 \mathrm{C}), 134.8,134.5,134.4,129.4,129.3,127.4(2 \mathrm{C}), 127.3$ (2C), 117.5, 108.5, 96.2, 81.5, 78.4, 77.1, 69.4, 55.8, 39.3, 35.6, 34.4, 27.4, 27.0, 26.9 (3C), 23.0, 21.7, 19.2. MS (ESI): $m / z 563$ [M+Na]. HRMS (ESI): calcd for $\mathrm{C}_{32} \mathrm{H}_{48} \mathrm{O}_{5} \mathrm{SiNa} 563.3163$, found 563.3148 .

$(S)-1-[(4 S, 5 S)-5-[(S)-1-(M e t h o x y m e t h y l o x y) b u t-3-e n-1-y l]-2,2-d i m e t h y l-1,3-d i o x o l a n-4-y l]-$ propan-2-ol (8). To a solution of $18(0.2 \mathrm{~g}, 0.37 \mathrm{mmol})$ in THF $(5 \mathrm{~mL})$ at $0{ }^{\circ} \mathrm{C}$, was added TBAF ( $1 \mathrm{M}$ solution in THF, $0.74 \mathrm{~mL}, 0.74 \mathrm{mmol})$. After stirring for $5 \mathrm{~h}$ at room temperature, the mixture was diluted with EtOAc, washed with $\mathrm{H}_{2} \mathrm{O}(10 \mathrm{~mL})$ and brine $(10 \mathrm{~mL})$, dried over $\mathrm{Na}_{2} \mathrm{SO}_{4}$, concentrated under reduced pressure. The residue was purified by silica gel column chromatography (hexane/EtOAc 8:2) to give 8 as colorless liquid $(0.108 \mathrm{~g}, 97 \%) . R_{f} 0.2$ (hexane/EtOAc 8:2); $[\alpha]^{20}{ }_{D}-1.17\left(c 0.6, \mathrm{CHCl}_{3}\right)$. IR (neat): 3447, 2927, 2855, 1737, 1461, 1377, 1216, 1103, 1038, $761 \mathrm{~cm}^{-1} .{ }^{1} \mathrm{H}$ NMR $\left(300 \mathrm{MHz}, \mathrm{CDCl}_{3}\right): \delta 5.91-5.83(\mathrm{~m}, 1 \mathrm{H}), 5.15-5.08(\mathrm{~m}$, $2 \mathrm{H}), 4.69(\mathrm{q}, J 6.6 \mathrm{~Hz}, 2 \mathrm{H}), 4.0-3.94(\mathrm{~m}, 1 \mathrm{H}), 3.84-3.78(\mathrm{~m}, 1 \mathrm{H}), 3.74-3.70(\mathrm{~m}, 2 \mathrm{H}), 3.38(\mathrm{~s}$, $3 \mathrm{H}), 2.40-2.38(\mathrm{~m}, 2 \mathrm{H}), 1.70-1.48(\mathrm{~m}, 6 \mathrm{H}), 1.38(\mathrm{~s}, 3 \mathrm{H}), 1.37(\mathrm{~s}, 3 \mathrm{H}), 1.19(\mathrm{~d}, J 6.1 \mathrm{~Hz}, 3 \mathrm{H}) .{ }^{13} \mathrm{C}$ NMR (75 MHz, $\left.\mathrm{CDCl}_{3}\right): \delta 134.2,117.5,108.5,96.2,81.5,78.5,77.2,67.9,55.8,39.1,35.6$, 34.2, 27.4, 27.0, 23.4, 22.3. MS (ESI): $\mathrm{m} / z 325$ [M+Na]. HRMS (ESI): calcd for $\mathrm{C}_{16} \mathrm{H}_{30} \mathrm{NaO}_{5}$ 325.1990 , found 325.1999 .

$(S)-5-\{(4 S, 5 S)-4-[(S)-1-(M e t h o x y m e t h o x y) b u t-3-e n-1-y l]-2,2-d i m e t h y l-1,3-d i o x o l a n-4-$ yl\}pentan-2-yl 2-hydroxy-4-methoxy-6-vinylbenzoate (23). To the solution of compound 8 (50 $\mathrm{mg}, 0.165 \mathrm{mmol}$ ), acid $\mathbf{9}^{19,21}$ (32 $\mathrm{mg}, 0.165 \mathrm{mmol}$ ) and DMAP (22 $\left.\mathrm{mg}, 0.182 \mathrm{mmol}\right)$ in THF (5 $\mathrm{mL})$ was added DCC $(37 \mathrm{mg}, 0.182 \mathrm{mmol})$ at $0{ }^{\circ} \mathrm{C}$, allowed to stir about $12 \mathrm{~h}$ till the complete disappearance of the starting materials (TLC). After $12 \mathrm{~h}$, EtOAc $(10 \mathrm{~mL})$ and $\mathrm{H}_{2} \mathrm{O}(10 \mathrm{~mL})$ were added. The layers were separated and the aqueous phase extracted with EtOAc $(2 \times 10$ $\mathrm{mL})$. The combined organic portions were washed with brine solution $(10 \mathrm{~mL})$, dried over $\mathrm{Na}_{2} \mathrm{SO}_{4}$, concentrated under reduced pressure, the residue was purified by silica gel column chromatography (hexane/EtOAc 95:5) to give $\mathbf{2 3}$ as colorless syrup (52 $\mathrm{mg}, 67 \%$ ). $R_{f} 0.4$ (hexane/EtOAc 8:2); $[\alpha]^{20}{ }_{\mathrm{D}}+7.5\left(c\right.$ 0.8, $\left.\mathrm{CHCl}_{3}\right)$. IR (neat): 3448, 3168, 2921, 2851, 1647, 1609, 1573, 1385, 1257, 1209, 1159, 1036, 916, $770 \mathrm{~cm}^{-1} .{ }^{1} \mathrm{H}$ NMR $\left(300 \mathrm{MHz}, \mathrm{CDCl}_{3}\right): \delta 11.80(\mathrm{~s}$, $1 \mathrm{H}), 7.27(\mathrm{dd}, J 17.2,10.8 \mathrm{~Hz}, 1 \mathrm{H}), 6.47(\mathrm{~d}, J 2.6 \mathrm{~Hz}, 1 \mathrm{H}), 6.40(\mathrm{~d}, J 2.6 \mathrm{~Hz}, 1 \mathrm{H}), 5.92-5.78(\mathrm{~m}$, $1 \mathrm{H}), 5.40(\mathrm{dd}, J 17.1,1.6 \mathrm{~Hz}, 1 \mathrm{H}), 5.22-5.14(\mathrm{~m}, 2 \mathrm{H}), 5.10-5.06(\mathrm{~m}, 1 \mathrm{H}), 4.67(\mathrm{q}, J 6.8 \mathrm{~Hz}, 2 \mathrm{H})$, 
3.96-3.90 (m, 1H), $3.81(\mathrm{~s}, 3 \mathrm{H}), 3.74-3.66(\mathrm{~m}, 2 \mathrm{H}), 3.39-3.35(\mathrm{~m}, 1 \mathrm{H}), 3.33(\mathrm{~s}, 3 \mathrm{H}), 2.39-2.35$ $(\mathrm{m}, 2 \mathrm{H}), 1.78-1.48(\mathrm{~m}, 6 \mathrm{H}), 1.37(\mathrm{~s}, 3 \mathrm{H}), 1.36(\mathrm{~s}, 3 \mathrm{H}), 1.35(\mathrm{~s}, 3 \mathrm{H}) .{ }^{13} \mathrm{C}$ NMR $\left(75 \mathrm{MHz}, \mathrm{CDCl}_{3}\right)$ : $\delta 170.7,164.9,163.9,143.7,138.6,134.2$ (2C), 117.6, 115.3, 108.6, 108.2, 100.2, 96.1, 81.5, $78.5,77.2,72.6,55.8,55.3,35.7,35.6,34.1,27.3,27.0,22.0,19.9$. MS (ESI): $m / z 501[\mathrm{M}+\mathrm{Na}]$. HRMS (ESI): calcd for $\mathrm{C}_{26} \mathrm{H}_{38} \mathrm{NaO}_{8} 501.2464$, found 501.2452.

(3aS,7S,17S,17aS,E)-10-Hydroxy-12-methoxy-17-(methoxymethyloxy)-2,2,7-trimethyl-3a,4,5,6,7,16,17,17a-octahydro-9H-benzo $[c][1,3]$ dioxolo[4,5-i] [1] oxacyclotetradecin-9-one (24). ${ }^{19}$

A solution of compound 23 (50 mg, $0.104 \mathrm{mmol})$ in $\mathrm{CH}_{2} \mathrm{Cl}_{2}(75 \mathrm{~mL})$ was treated with $5 \mathrm{~mol} \%$ of Grubbs second generation catalyst and allowed to stir for $48 \mathrm{~h}$. The reaction mixture was filtered through a pad of $\mathrm{SiO}_{2}$, washed with $\mathrm{CH}_{2} \mathrm{Cl}_{2}$ and concentrated under reduced pressure. Purification by silica gel column chromatography (hexane/EtOAc 9:1) gave $\mathbf{2 4}$ as a white solid (40 mg, 85\%). $R_{f} 0.3$ (hexane/EtOAc 8:2); mp $119{ }^{\circ} \mathrm{C} ;[\alpha]^{20}{ }_{\mathrm{D}}-131.49\left(c 1.16, \mathrm{CHCl}_{3}\right)$. IR (KBr): 2982, 2933, 1647, 1608, 1574, 1445, 1376, 1357, 1319, 1257, 1211, 1159, 1103, 1034, 967, 864, $757 \mathrm{~cm}^{-1} .{ }^{1} \mathrm{H}$ NMR $\left(300 \mathrm{MHz}, \mathrm{CDCl}_{3}\right): \delta 11.92(\mathrm{~s}, 1 \mathrm{H}), 7.15(\mathrm{dd}, J 15.8,2.2 \mathrm{~Hz}, 1 \mathrm{H}), 6.40(\mathrm{~s}$, 2H), 5.80-5.70 (m, 1H), 5.17-5.06 (m, 1H), 4.79 (q, J 6.7 Hz, 2H), 4.30-4.26 (m, 1H), 4.16-4.08 $(\mathrm{m}, 1 \mathrm{H}), 3.87(\mathrm{dd}, J 8.3,1.5 \mathrm{~Hz}, 1 \mathrm{H}), 3.82(\mathrm{~s}, 3 \mathrm{H}), 3.42(\mathrm{~s}, 3 \mathrm{H}), 2.78-2.69(\mathrm{~m}, 1 \mathrm{H}), 2.39-2.26(\mathrm{~m}$, 1H), 1.84-1.53 (m, 6H), $1.42(\mathrm{~d}, J 6.0 \mathrm{~Hz}, 3 \mathrm{H}), 1.38(\mathrm{~s}, 3 \mathrm{H}), 1.32(\mathrm{~s}, 3 \mathrm{H}) .{ }^{13} \mathrm{C}$ NMR $(75 \mathrm{MHz}$, $\left.\mathrm{CDCl}_{3}\right): \delta 171.1,165.2,163.8,142.6,133.9,128.4,123.5,108.6,100.2,96.9,78.9,74.9,74.1$, $73.2,55.5,55.3,36.5,35.5,32.5,27.2,26.8,20.1,18.9$. MS (ESI): $m / z 473$ [M+Na]. HRMS (ESI): calcd for $\mathrm{C}_{24} \mathrm{H}_{34} \mathrm{NaO}_{8} 473.2151$, found 473.2151 .

Paecilomycin F (7). A solution of compound $24(40 \mathrm{mg}, 0.067 \mathrm{mmol})$ in THF (5 mL) was treated with $2 \mathrm{~N} \mathrm{HCl}(5 \mathrm{~mL})$ and allowed to stir for $15 \mathrm{~h}$, then EtOAc $(5 \mathrm{~mL})$ and $\mathrm{H}_{2} \mathrm{O}(5 \mathrm{~mL})$ were added. The layers were separated and the aqueous phase was extracted with EtOAc $(2 \mathrm{x} 5$ $\mathrm{mL})$. The combined organic portion was washed with saturated sodium bicarbonate solution (10 $\mathrm{mL})$ followed by brine solution $(10 \mathrm{~mL})$, dried over $\mathrm{Na}_{2} \mathrm{SO}_{4}$, and then concentrated under reduced pressure, the residue was purified by silica gel column chromatography (hexane/EtOAc 4:6) to give paecilomycin F 7 as white solid (21 mg, 87\%). $R_{f} 0.4$ (EtOAc 100\%); mp 166-168 ${ }^{\circ} \mathrm{C} ;[\alpha]{ }_{\mathrm{D}}^{20}-93.83(c \mathrm{0.12}, \mathrm{MeOH}) .\left(\right.$ Lit. $^{13}[\alpha]{ }^{20}{ }_{\mathrm{D}}-96.4(c$ 0.28, MeOH$),\left(\right.$ Lit. $^{21}[\alpha]{ }_{\mathrm{D}}^{20}-94.0(c$ $0.28, \mathrm{MeOH})$; IR (KBr): 3448, 2926, 1616, 1595, 1508, 1367, 1264, 1153, 1087, 1012, 964 , 778, $691 \mathrm{~cm}^{-1} .{ }^{1} \mathrm{H}$ NMR $\left(500 \mathrm{MHz}, \mathrm{CDCl}_{3}\right): \delta 12.22(\mathrm{~s}, 1 \mathrm{H}), 7.12(\mathrm{~d}, J 14.8 \mathrm{~Hz}, 1 \mathrm{H}), 6.38(\mathrm{~s}$, 2H), 5.70-5.64 (m, 1H), 5.00-4.90 (m, 1H), 4.19-4.13 (m, 2H), $3.79(\mathrm{~s}, 3 \mathrm{H}), 3.52(\mathrm{~s}, 1 \mathrm{H}), 2.69-$ $2.66(\mathrm{~m}, 1 \mathrm{H}), 2.52-2.44(\mathrm{~m}, 1 \mathrm{H}), 1.96-1.78(\mathrm{~m}, 2 \mathrm{H}), 1.64-1.41(\mathrm{~m}, 2 \mathrm{H}), 1.38(\mathrm{~d}, J 5.9 \mathrm{~Hz}, 3 \mathrm{H})$, 1.34-1.28 (m, 2H). ${ }^{13} \mathrm{C}$ NMR (75 MHz, $\left.\mathrm{CDCl}_{3}\right): \delta 171.4,165.9,164.0,142.9,134.1,127.3$, 109.0, 103.3, 100.2, 76.1, 73.7, 68.8, 66.9, 55.4, 38.7, 35.2, 30.9, 21.2, 20.9. MS (ESI): $\mathrm{m} / \mathrm{z} 389$ [M+Na]. HRMS (ESI): calcd for $\mathrm{C}_{19} \mathrm{H}_{26} \mathrm{NaO}_{7} 389.1576$, found 389.1591 . 


\section{Acknowledgements}

B.M. thanks UGC, New Delhi for financial support in the form of a fellowship. P.S. acknowledges research Grant (P-81-113) from the Human Resources Research Group - New Delhi through the Council of Scientific \& Industrial Research (CSIR) Young Scientist Award Scheme. The authors also thank CSIR, New Delhi for partial funding from XII Five year plan programme ORIGIN under the budget head CSC-108.

\section{References}

1. Fujita, K-I.; Irie, M.; Ping, X,; Taniguchi, M. J. Biosci. Bioeng. 1999, 88, 380-386. http://dx.doi.org/10.1016/S1389-1723(99)80214-X

2. Delmotte, P.; Delmotte-Plaquée, J. Nature 1953, 171, 344-345. http://dx.doi.org/10.1038/171344a0

3. Roe, S. M.; Prodromou, C.; O’Brien, R.; Ladbury, J. E.; Piper, P. W.; Pearl, L. H. J. Med. Chem. 1999, 42, 260-266. http://dx.doi.org/10.1021/jm980403y

4. Chanmugam, P.; Feng, L.; Liou, S.; Jang, B. C.; Boudreau, M.; Yu, G.; Lee, J. H.; Kwon, H. J.; Beppu, T.; Yoshida, M.; Xia, Y.; Wilson, C. B.; Hwang, D. J. Biol. Chem. 1995, 270, 5418-5426. http://dx.doi.org/10.1039/B610344H

5. Wissinger, N.; Barluenga, S. Chem. Commun. 2007, 22-36. http://dx.doi.org/10.1039/B610344H

6. Isaka, M.; Suyarnsestakorn, C.; Tanticharoen, M.; Kongsaeree, P.; Thebtaranonth, Y. J. Org. Chem. 2002, 67, 1561-1566. http://dx.doi.org/10.1021/jo010930g

7. Hellwig, V.; Mayer-Bartschmid, A.; Mueller, H.; Greif, G.; Kleymann, G.; Zitzmann, W.; , H-V.; Stadler, M. J. Nat. Prod. 2003, 66, 829-837. http://dx.doi.org/10.1021/np020556v

8. Ayer, W. A.; Lee, S. P.; Tsuneda, A.; Hiratsuka, Y. Can. J. Microbiol. 1980, 26, 766-773. http://dx.doi.org/10.1139/m80-133

9. Ayers, S.; Graf, T. N.; Adcock, A. F.; Kroll, D. J.; Matthew, S.; Carcche de Blanco, E. J.; Shen, Q.; Swanson, S. M.; Wani, M. C.; Pearce, C. J.; Oberlies, N. H. J. Nat. Prod. 2011, 74, 1126-1131. http://dx.doi.org/10.1021/np200062x

10. Boettger-Tong, H.; Murthy, L.; Chiappetta, C.; Kirkland, J. L.; Goodwin, B.; Adlercreutz, H.; Stancel, G. M.; Makela, S. Environ Health Perspect. 1998, 106, 369-373. http://dx.doi.org/10.1289/ehp.98106369 
11. Dong, J.; Zhu, Y.; Song, H.; Li, R.; He, H.; Liu, H.; Huang, R.; Zhou, Y.; Wang, L.; Cao, Y.; Zhang, K. J. Chem. Ecol. 2007, 33, 1115-1126. http://dx.doi.org/10.1007/s10886-007-9256-7

12. Winssinger, N.; Fontaine, J.-G.; Barluenga, S. Curr. Top. Med. Chem. 2009, 9, 1419-1435. http://dx.doi.org/10.2174/156802609789895665

13. Dutton, B. L.; Kitson, R. R. A.; Parry-Morris, S.; Roe, S. M.; Prodromou, C.; Moody, C. J. Org. Biomol. Chem. 2014, 12, 1328-1340. http://dx.doi.org/10.1039/c3ob42211a

14. Ting, S. Z. Y.; Baird, L. J.; Dunn, E.; Hanna, R.; Leahy, D.; Chan, A.; Miller, J. H.; Teesdale-Spittle, P. H.; Harvey, J. E. Tetrahedron 2013, 69, 10581-10592. http://dx.doi.org/10.1016/j.tet.2013.10.042

15. Xu, J.; Chen, A.; Joy, J.; Xavier, V. J.; Ong, E. H. Q.; Hill, J.; Chai, C. L. L. ChemMedChem 2013, 8, 1483-1494. http://dx.doi.org/10.1002/cmdc.201300231

16. Xu, L.; He, Z.; Xue, J.; Chen, X.; Wei, X. J. Nat. Prod. 2010, 73, 885-889. http://dx.doi.org/10.1021/np900853n

17. Shao, C.-L.; Wu, H.-X.; Wang, Ch.-Y.; Liu, Q.-A.; Xu, Y.; Wei, M.-Y.; Qian, P.-Y., Gu, Y.C.; Zheng, C. -J.; She, Z. -G.; Lin, Y.-C. J. Nat. Prod. 2011, 74, 629-633. http://dx.doi.org/10.1021/np100641b

18. Xu, L.; He, Z.; Xue, J.; Chen, X.; Wei, X. J. Nat. Prod. 2012, 75, 1006-1006. http://dx.doi.org/10.1021/np100641b

19. Srihari, P.; Mahankali, B.; Rajendraprasad, K. Tetrahedron Lett. 2012, 53, 56-58. http://dx.doi.org/10.1016/j.tetlet.2011.10.137

20. Mohapatra, D. K.; Sai Reddy, D.; Mallampudi, N. A.; Yadav, J. S. Eur. J. Org. Chem. 2014, 5023-5032. http://dx.doi.org/10.1002/ejoc.201402133

21. Mahankali, B.; Srihari, P. Eur. J. Org. Chem. 2015, 3983-3993. http://dx.doi.org/10.1002/ejoc.201500395

22. Srihari, P.; Harikrishna, N. Sridhar, Y.; Kamal, A. Beilstein J. Org. Chem. 2014, 10, 31223126. http://dx.doi.org/10.3762/bjoc.10.329

23. Srihari, P.; Harikrishna, N.; Sridhar, Y.; Krishnam Raju, A.; Kamal, A. RSC Advances 2014, 4, 37629-37636. http://dx.doi.org/10.1039/C4RA06373B

24. Vamshikrishna, K. Srinu, G.; Srihari, P. Tetrahedron: Asymm. 2014, 25, 203-211. http://dx.doi.org/10.1016/j.tetasy.2013.12.008

25. Sridhar, Y.; Srihari, P. Eur. J. Org. Chem. 2013, 578-587. http://dx.doi.org/10.1002/ejoc.201201155 
26. Srihari, P.; Satyanarayana, K.; Ganganna, B.; Yadav, J. S. J. Org. Chem. 2011, 76, $1922-$ 1925 http://dx.doi.org/10.1021/jo102401v

27. Srihari, P.; Sridhar, Y. Eur. J. Org. Chem. 2011, 33, 6690-6697. http://dx.doi.org/10.1002/ejoc.201100917

28. For synthesis of 5'-epi-paecilomycin F see Jana, N.; Nanda, S. Tetrahedron: Asymm. 2012, 23, 802-808.

29. Onoda, T.; Shirai, R.; Kawai, N.; Iwasaki, S. Tetrahedron 1996, 52, 13327-13338. http://dx.doi.org/10.1016/0040-4020(96)00792-2

30. Ichikawa, Y.; Matsunaga, K.; Masuda, T.; Kotsuki, H.; Nakano, K. Tetrahedron 2008, 64, 11313-11318. http://dx.doi.org/10.1016/j.tet.2008.09.036

31. Mancuso, A. J.; Huang, S.-L.; Swern, D. J. Org. Chem. 1978, 43, 2480-2482. http://dx.doi.org/10.1021/jo00406a041

32. Chattopadhyay, A.; Dhotare, B. Tetrahedron: Asymm. 1998, 9, 2715-2723. http://dx.doi.org/10.1016/S0957-4166(98)00282-1

33. Dushin, R. G.; Danishefsky, S. J. J. Am. Chem. Soc. 1992, 114, 655-659. http://dx.doi.org/10.1021/ja00028a035

34. Mitsunobu, O. Synthesis 1981, 1-28. http://dx.doi.org/10.1055/s-1981-29317

35. Farina, V.; Krishnan, B. J. Am. Chem. Soc. 1991, 113, 9585-9595. http://dx.doi.org/10.1021/ja00025a025

36. Neises, B.; Steglich, W. Angew. Chem. Int. Ed. 1978, 17, 522-524. http://dx.doi.org/10.1002/anie.197805221

37. Scholl, M.; Ding, S.; Lee, C. W.; Grubbs, R. H. Org. Lett. 1999, 1, 953-956. http://dx.doi.org/10.1021/o1990909q

38. Vrbkova, S.; Dračínsky, M.; Holý, A. Tetrahedron: Asymm. 2007, 18 2233-2247. http://dx.doi.org/10.1016/j.tetasy.2007.09.021

39. Hamamsy, M. H. R.; Smith, W. A.; Thompson, S. A.; Threadgill, M. D. Bioorg. Med. Chem. 2007, 15, 4552-4576. http://dx.doi.org/10.1016/j.bmc.2007.04.011 